\title{
Amphibians in a transition region between the Cerrado and the Atlantic Forest, west-central region of the state of São Paulo, Brazil
}

\author{
Anfíbios em uma região de transição entre o Cerrado e a Mata \\ Atlântica, Região Centro-Oeste do estado de São Paulo, Brasil
}

\author{
Daniel Contieri Rolim ${ }^{1}$
}

\begin{abstract}
Studies of the diversity and natural history of amphibians are extremely important and contribute with the knowledge about the patterns of geographical distribution and biology of the species, outlining the factors that influence this distribution, and contributing to the development of conservation projects of them. This study aimed to identify the richness, abundance, spatial and temporal distribution of amphibians in the Bauru region, state of São Paulo, Brazil, and compare the species composition with others regions in the São Paulo state located in the Cerrado and Atlantic Forest. Eight locations were sampled between the years 2009 and 2012. Thirty-seven amphibian species were recorded, which represents $15.61 \%$ of the species in the state of São Paulo. In comparison to other regions of the state, Bauru resemble with the north-western region of the state and with the Assis Ecological Station in species composition. The community of amphibians in the studied region is regulated to morphoclimatic conditions, environmental heterogeneity and the conservation of natural resources, which directly reflect on the composition, abundance and species' spatial and temporal distribution of the amphibians in this region. The richness of amphibians of the Bauru region is significant for the state of São Paulo and contributes with the maintenance of environments with conditions for the occurrence of Proceratophrys moratoi, which is considered in threat of extinction. This study contributed with the filling gap on the amphibian knowledge of the state of São Paulo.
\end{abstract}

Keywords: Anurans; Natural history; Diversity; Conservation.

\section{Resumo}

Estudos sobre diversidade e história natural de anfíbios são de extrema importância para o conhecimento sobre os padrões de distribuição geográfica e biologia das espécies delineando os fatores que influenciam nessa distribuição, o que contribui para a elaboração de projetos de conservação mais realistas e efetivos. Este estudo visou identificar a riqueza, abundância, distribuição espacial e temporal das espécies de anfíbios da região de Bauru, estado de São Paulo, Brasil, e comparar a composição de espécies com outras regiões de Cerrado e Mata Atlântica do estado de São Paulo. Oito localidades foram amostradas entre os anos de 2009 e 2012. Foram registradas 37 espécies de anfíbios, as quais representam 15,61\% das espécies do estado de São Paulo. Em comparação com

\footnotetext{
${ }^{1}$ Doutorado em Ciências Biológicas (Área de Zoologia) pelo Instituto de Biociências da Universidade Estadual Paulista "Júlio de Mesquita Filho" (IBB-Unesp), Botucatu, São Paulo, Brasil. Biólogo da Secretaria Municipal do Meio Ambiente (SEMMA), Bauru, São Paulo, Brasil. E-mail: danielcrolim@gmail.com
} 
outras regiões do estado, Bauru se assemelha à Região Noroeste do estado e à Estação Ecológica de Assis na composição de espécies. A comunidade de anfíbios da região estudada é regulada pelas condições morfoclimáticas, heterogeneidade ambiental e estado de conservação dos recursos naturais, que refletem diretamente na composição, na abundância e nos padrões de distribuição espacial e temporal das espécies de anfíbios presentes na região. A riqueza de anfíbios da região de Bauru é significativa para o estado de São Paulo e contribui com a manutenção de ambientes com condições para a ocorrência de Proceratophrys moratoi, considerada em risco de extinção. Este estudo contribui com o preenchimento de lacunas no conhecimento de anfíbios do estado de São Paulo.

Palavras-chave: Anuros; História natural; Diversidade; Conservação.

\section{Introduction}

Brazil has the most diversity of amphibians in the world, with a total of 1080 species, where 1039 are Anura, 5 are Caudata and 36 are Gymnophiona. ${ }^{(1)}$ The state of São Paulo represents approximately $25 \%$ of the diversity of the country, with 237 species. ${ }^{(2,3)}$ However, there are a lot of gaps in the sampling of amphibians in the state, and the Bauru region has a low level of knowledge in the sampling of these organisms. ${ }^{(3)}$

The Bauru region is situated in an area of contact between the Cerrado and the Atlantic Forest. ${ }^{(4)}$ The Cerrado is the second biggest Brazilian biome in terms of extension, with more than 2,000,000 $\mathrm{km}^{2}{ }^{(5)}$ In the last 35 years, more than half of the Cerrado area was turned into pasture and plantations, ${ }^{(6)}$ and the conservation unities cover less than $2 \%$ of its total area. ${ }^{(5)}$ The state of São Paulo, which originally had circa $34,700 \mathrm{~km}^{2}$ of Cerrado (14\% of its total area), is in a more serious situation, since the reminiscent of this vegetation covers circa $2,100 \mathrm{~km}^{2}$, corresponding to $0.84 \%$ of the state's total area and just half of what is left is protected as conservation unity. ${ }^{(7)}$ The Atlantic Forest was deforest in more than $88 \%$ and only still remains $12 \%$ of original area. ${ }^{(8)}$ In the São Paulo state interior, only $7 \%$ of the Atlantic Forest fragments remaining. ${ }^{(8)}$ There are at least 209 known species of amphibians in Cerrado, and approximately $52 \%$ of these species are endemic of this biome. ${ }^{(9)}$ For the Atlantic Forest are know 540 amphibians species and 90\% of these species are endemic of this biome. ${ }^{(10)}$

In recent years there has been a significant increase in the number of published studies on the diversity of amphibians in the Cerrado and seasonal forest in the state of São Paulo. Few studies describe the taxocenoses of anurans of the Cerrado and its ecotone with the Semideciduous Seasonal Forest of São Paulo, with a special attention given to those conducted in Guararapes, ${ }^{(11)}$ Rio Claro, ${ }^{(12)}$ Itirapina and Brotas, ${ }^{(13)}$ Assis, ${ }^{(14)}$ Luiz Antonio, ${ }^{(15)}$ Pedregulho, ${ }^{(16)}$ Avaré, ${ }^{(17)}$ Águas de Santa Bárbara, ${ }^{(18)}$ Angatuba, ${ }^{(19)}$ Anhembi, ${ }^{(20)}$ Jaú and Agudos, ${ }^{(21)}$ Vassununga, ${ }^{(22)}$ and Bauru. ${ }^{(23)}$ The strong anthropic pressure, the high level of endemism and the decline in anurans populations registered in this biome reinforce the importance of taxonomical inventories and studies about the ecology of anurans in Cerrado areas.

Therefore, amphibian inventories are extremely important and they contribute with the knowledge about the geographical distribution patterns and the biology of the species, outlining the factors that affect this distribution, which will contribute to the elaboration of conservation projects for them. This study aimed to identify the richness, abundance and spatial and temporal distribution of the amphibian species of Bauru region and to compare to studies done in other regions of the state of São Paulo located in Cerrado and Atlantic Forest.

\section{Material and Methods}

\section{Study area}

Eight localities were sampled in the Bauru region (Figure 1), covering a radius of up to 30 $\mathrm{km}$ of range around the urban area of the city, contemplating six cities. The areas was: two in 
the municipality of Bauru: Localidade 1 - Jardim Botânico Municipal de Bauru (22²0'48.46”'S; 490'56.73"W, Elevation: $550 \mathrm{~m})$, Localidade 2 - Instituto Lauro Souza Lima (22²0’29.10’'S; 48 58'59.40”'W, Elevation: $530 \mathrm{~m}$ ); two in the municipality of Agudos: Localidade 3 - Fazenda São Benedito (22²8'53.90’'S; 49²'8.80’W, Elevation: $659 \mathrm{~m})$, Localidade 4 - Pesqueiro Toca do Peixe $\left(22^{\circ} 28^{\prime} 38.80^{\prime \prime} \mathrm{S}\right.$; 49²'16.10”W, Elevation: $568 \mathrm{~m}$ ); one in the municipality of Iacanga:
Localidade 5 - Fazenda Pindorama (21 $58^{\prime} 46.60^{\prime}$ S; 49²'17.30"W, Elevation: $427 \mathrm{~m}$ ); one in the municipality of Piratininga: Localidade 6 - Sítio Piratininga (22²4'20.30”'S; 496'13.90'W, Elevation: $490 \mathrm{~m})$, one in the municipality of Avaí: Localidade 7 - Fazenda Rio Batalha (22²’34.60”S; 49¹4'59.50"W, Elevation: $419 \mathrm{~m}$ ) and one in the municipality of Pederneiras: Localidade 8 Reserva Legal do Horto Aimorés (22 17 '55.53”S; 485'02.92”'W, Elevation: $534 \mathrm{~m})$.

Figure 1 - Map of the state of São Paulo, showing the original vegetation distribution and in detail the 8 localities sampled in the cities of the Bauru region: 1. Jardim Botânico Municipal de Bauru; 2. Instituto Lauro Souza Lima; 3. Fazenda São Benedito; 4. Pesqueiro Toca do Peixe; 5. Fazenda Pindorama; 6. Sítio Piratininga; 7. Fazenda Rio Batalha; 8. Reserva Legal do Horto Aimorés.

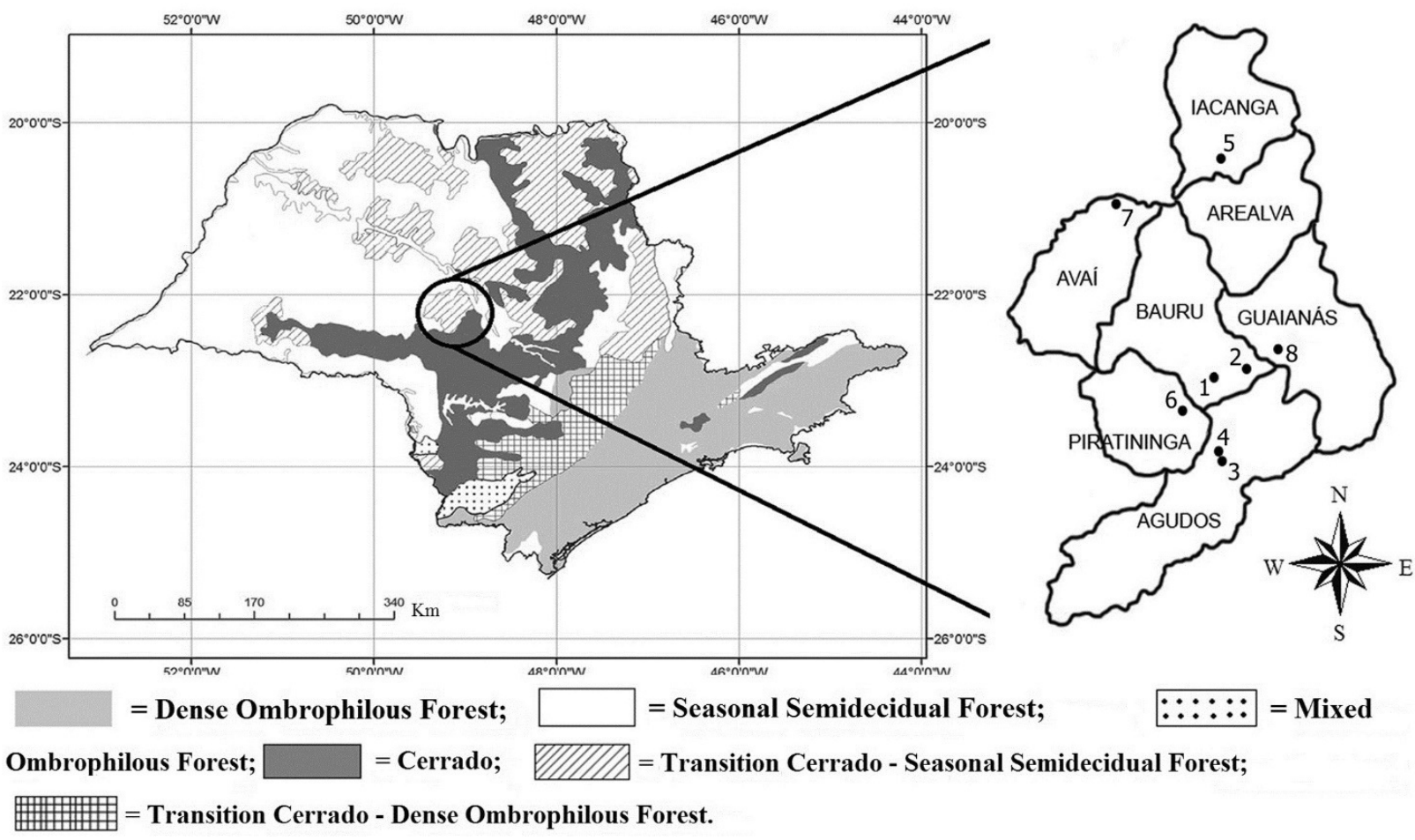

Source: adaptation of Siqueira and Durigan. ${ }^{(4)}$

The region's vegetation is characterized by fragments of Forest Savannah (Cerradão) and Atlantic Forest. ${ }^{(4)}$ The climate, according to the KöppenGeiger classification is temperate, with dry winters and hot summers (Cwa). ${ }^{(24)}$ And according the map of climatic division of the state of São Paulo, Bauru shows average temperatures higher than $22{ }^{\circ} \mathrm{C}$ at the hottest months and lower than $18{ }^{\circ} \mathrm{C}$ at the coldest months. ${ }^{(25)}$ The area is situated in the Western
Highlands, with an average altitude of $525 \mathrm{~m} .{ }^{(25)} \mathrm{In}$ the last ten years previous to this study, it has shown an average annual rainfall of $1,200 \mathrm{~mm} \cdot{ }^{(26)}$

\section{Characterization of the studied localities and water bodies}

The environments of each of the sampled localities were characterized according to their 
location, elevation (meters), water body type, fragment or inside the forest fragment). It was physiognomy (Cerrado or Atlantic Forest), water body features (duration, movement, size and soil), considered an open area when it was more than 50 vegetation type that compose (arboreal and herbaceous, shrubby, macrophytes) and localization of the water bodies (open area, associated to a forest meters away from the forest area and associated to a forest fragment when it was located at the border or at less than 50 meters from a forest fragment (Table 1).

Table 1 - Characterization of breeding habitats, according to their location, elevation (meters), water body type, physiognomy, water body features (duration, movement, size and soil) and vegetation type that compose (arboreal and herbaceous, shrubby, macrophytes). Abbreviations: DUR = duration; MOV = movement; SIZ = size; $\mathrm{SOI}=$ bed soil; Per = permanent; $\mathrm{T}=$ temporary; $\mathrm{Ec}=$ exchange constant; $\mathrm{S}=$ standing; $\mathrm{Cu}=$ current; $\mathrm{Sma}=$ small; $\mathrm{Med}=$ medium; Lar = large; Roc = rocky; San = sandy; Mud = muddy; $\mathrm{HB}=$ herbaceous vegetation; $\mathrm{SH}=$ shrubby; $\mathrm{AB}=$ arboreal; $\mathrm{MA}=$ macrophytes; $++=$ presence and very abundant; $+=$ presence; $-=$ absence.

\begin{tabular}{|c|c|c|c|c|c|c|c|c|c|}
\hline \multirow{2}{*}{$\begin{array}{l}\text { Localities, } \\
\text { coordinates }\end{array}$} & \multirow{2}{*}{$\begin{array}{l}\text { Water body type } \\
\text { and physiognomy }\end{array}$} & \multicolumn{4}{|c|}{ Features } & \multicolumn{4}{|c|}{ Vegetation type } \\
\hline & & DUR & MOV & SIZ & SOI & HB & SH & $\mathbf{A B}$ & MA \\
\hline \multirow{12}{*}{$\begin{array}{l}\text { L. } 1 \\
\text { Jardim } \\
\text { Botânico } \\
\text { Municipal } \\
\text { de Bauru }\end{array}$} & Fountain in open area & $\mathrm{T}$ & $\mathrm{Ec}$ & Sma & San & ++ & ++ & + & - \\
\hline & Stream on edge forest & Per & $\mathrm{Cu}$ & Sma & San & ++ & ++ & + & + \\
\hline & Dam in open area & Per & S & Sma & Mud & + & - & - & + \\
\hline & Swamp on edge forest & Per & Ec & Lar & Mud & ++ & ++ & + & ++ \\
\hline & Dam on edge forest & Per & S & Lar & Mud & ++ & ++ & + & + \\
\hline & Swamp in open area & Per & Ec & Med & Mud & ++ & + & + & ++ \\
\hline & Dam on edge forest & Per & S & Sma & Mud & ++ & + & + & ++ \\
\hline & Stream in galery forest & Per & $\mathrm{Cu}$ & Sma & San & + & + & ++ & + \\
\hline & Dam on edge forest & Per & S & Sma & Mud & + & + & + & + \\
\hline & Stream in swampy forest & Per & $\mathrm{Cu}$ & Sma & San & + & ++ & ++ & + \\
\hline & Ponds in swampy forest & Per & Ec & Sma & Mud & + & ++ & ++ & - \\
\hline & Dam in open area & Per & $\mathrm{Ec}$ & Med & Mud & + & - & - & + \\
\hline \multirow{2}{*}{$\begin{array}{l}\text { L. } 2 \\
\text { Instituto Lauro } \\
\text { Souza Lima }\end{array}$} & Dam on edge forest & Per & S & Med & Mud & ++ & ++ & ++ & + \\
\hline & Dam on edge forest & Per & S & Med & Mud & ++ & ++ & ++ & ++ \\
\hline \multirow{4}{*}{$\begin{array}{l}\text { L. } 3 \\
\text { Fazenda } \\
\text { São Benedito }\end{array}$} & Stream in galery forest & $\mathrm{P}$ & $\mathrm{Cu}$ & Sma & San/Roc & + & ++ & ++ & + \\
\hline & Pond in forest & $\mathrm{T}$ & S & Sma & San & + & + & + & - \\
\hline & Pond in eucalyptus & $\mathrm{T}$ & S & Sma & San & ++ & - & - & - \\
\hline & Pond on edge eucalyptus & $\mathrm{T}$ & S & Sma & San & + & - & + & - \\
\hline
\end{tabular}




\begin{tabular}{|c|c|c|c|c|c|c|c|c|c|}
\hline $\begin{array}{l}\text { L. } 4 \\
\text { Pesqueiro } \\
\text { Toca do Peixe }\end{array}$ & $\begin{array}{l}\text { Stream in galery forest } \\
\text { Pond on edge forest }\end{array}$ & $\begin{array}{l}\text { Per } \\
\mathrm{T}\end{array}$ & $\begin{array}{c}\mathrm{Cu} \\
\mathrm{S}\end{array}$ & $\begin{array}{l}\text { Sma } \\
\text { Med }\end{array}$ & $\begin{array}{l}\text { San/Roc } \\
\text { Mud }\end{array}$ & $\begin{array}{l}+ \\
+\end{array}$ & $\begin{array}{l}++ \\
-\end{array}$ & $\begin{array}{l}++ \\
-\end{array}$ & $\begin{array}{l}+ \\
+\end{array}$ \\
\hline \multirow{9}{*}{$\begin{array}{l}\text { L. } 5 \\
\text { Fazenda } \\
\text { Pindorama }\end{array}$} & Dam in open area & Per & $\mathrm{S}$ & Lar & Mud & ++ & ++ & + & ++ \\
\hline & Pond in open area & $\mathrm{T}$ & $\mathrm{S}$ & Med & Mud & ++ & ++ & + & + \\
\hline & Pond in open area & Per & $\mathrm{S}$ & Sma & Mud & ++ & + & + & ++ \\
\hline & Pond in open area & $\mathrm{T}$ & $\mathrm{S}$ & Sma & San & + & - & - & - \\
\hline & Pond on edge forest & $\mathrm{T}$ & $\mathrm{S}$ & Sma & San & + & ++ & ++ & - \\
\hline & Fountain in open area & Per & $\mathrm{Ec}$ & Lar & San & ++ & ++ & + & + \\
\hline & Swamp in open area & Per & $\mathrm{Ec}$ & Lar & San/Mud & ++ & ++ & + & + \\
\hline & Pond on edge eucalyptus & $\mathrm{T}$ & $\mathrm{S}$ & Sma & Mud & + & + & ++ & - \\
\hline & Pond on edge sugar cane & $\mathrm{T}$ & $\mathrm{S}$ & Sma & San & + & + & - & - \\
\hline \multirow{7}{*}{$\begin{array}{l}\text { L. } 6 \\
\text { Sítio } \\
\text { Piratininga }\end{array}$} & Stream in galery forest & Per & $\mathrm{Cu}$ & Sma & San & + & + & ++ & - \\
\hline & Fountain in open area & Per & $\mathrm{Ec}$ & Sma & San & ++ & ++ & + & + \\
\hline & Pond in open area & Per & $\mathrm{S}$ & Med & Mud & ++ & ++ & + & ++ \\
\hline & Swamp in open area & Per & $\mathrm{Ec}$ & Lar & Mud & ++ & ++ & + & ++ \\
\hline & Pond in open area & $\mathrm{T}$ & $\mathrm{S}$ & Sma & San & + & - & - & - \\
\hline & Pond in open area & $\mathrm{T}$ & $\mathrm{S}$ & Sma & San/Mud & ++ & + & - & + \\
\hline & Pond on edge forest & $\mathrm{T}$ & $\mathrm{S}$ & Sma & Mud & ++ & ++ & + & + \\
\hline \multirow{10}{*}{$\begin{array}{l}\text { L. } 7 \\
\text { Fazenda } \\
\text { Rio Batalha }\end{array}$} & Dam in open area & Per & $\mathrm{S}$ & Med & San/Mud & ++ & ++ & + & + \\
\hline & Ponds in open area & $\mathrm{T}$ & $\mathrm{Ec}$ & Med & San & ++ & + & + & + \\
\hline & Pond in forest & $\mathrm{T}$ & $\mathrm{S}$ & Sma & Mud & + & + & ++ & - \\
\hline & Pond in open area & $\mathrm{T}$ & $\mathrm{S}$ & Sma & San & ++ & - & - & - \\
\hline & Dam in open area & Per & $\mathrm{S}$ & Sma & Mud & ++ & + & + & ++ \\
\hline & Fountain on edge forest & Per & $\mathrm{Ec}$ & Med & San & ++ & + & + & + \\
\hline & Dam on edge forest & Per & $\mathrm{S}$ & Med & Mud & ++ & + & + & ++ \\
\hline & Pond in open area & $\mathrm{T}$ & $\mathrm{S}$ & Sma & Mud & ++ & + & - & ++ \\
\hline & Pond in forest & Per & $\mathrm{S}$ & Sma & Mud & + & ++ & ++ & + \\
\hline & Pond on edge forest & $\mathrm{T}$ & $\mathrm{S}$ & Sma & San & ++ & + & + & + \\
\hline \multirow{5}{*}{$\begin{array}{l}\text { L. } 8 \\
\text { Horto } \\
\text { Aimorés }\end{array}$} & Stream in forest & Per & $\mathrm{Ec}$ & Sma & San & ++ & + & ++ & - \\
\hline & Pond in forest & $\mathrm{T}$ & S & Sma & San & - & - & + & - \\
\hline & Swamp in open area & Per & $\mathrm{Ec}$ & Lar & San/Mud & ++ & + & - & ++ \\
\hline & Swamp on edge forest & Per & $\mathrm{Ec}$ & Lar & San/Mud & ++ & ++ & + & ++ \\
\hline & Pond on edge forest & $\mathrm{T}$ & $\mathrm{S}$ & Sma & San & + & + & + & - \\
\hline
\end{tabular}

Source: the author. 
Methods of sampling for the anuran fauna

The eight localities were sampled between the years 2009 and 2012. All of the permanent or temporary aquatic environments were sampled, in open or forest areas, presents in the localities. There were sampled streams, marshes, dams and pools, both in open area and forest phytophysiognomy. The localities were sampled during daytime and nighttime, where it was registered the occurrence of adults of all the anuran species presents at the location. The methods used in the search of individuals were: active visual search, hearing search (zoophonia) and sampling at the reproduction's locations. ${ }^{(27)}$

In each visit it was made an estimation of the number of individuals of the species in activity. The monthly abundance of each species was considered equal to the higher abundance registered at each month's visit and the total abundance in each environment or locality is equal to the month with higher abundance. ${ }^{(28)}$ For the abundance of each species at the Bauru region, it was used the number of individuals of the visit in which the species showed in higher abundance during the study in each locality and it was added to each locality the species was registered. These were distributed in six classes of abundance (Ca): (1): $<5$; (2): 5-10; (3): 11-20; (4): 21-50; (5): 50-100 and (6): >100. The temporal distribution of the species was registered along the year.

The conservation status of the species was considered according to the national and state lists of menaced species of Brazil ${ }^{(29-30)}$ and in IUCN Red List of Threatened Species. ${ }^{(31)}$ The nomenclature and classification presented follows Frost (2020). ${ }^{(32)}$

\section{Statistical analysis}

The efficiency of the samplings was measured by accumulative curves of species (Figure 5), generated by the species abundance data in the localities and on the 108 days of sampling (one sample = one day), using the program EstimateS v. 9.1.0 with 1000 randomizations (Colwell, 2016). ${ }^{(33)}$
There were used non-parametrical estimators Jackknife 1, which extrapolates the number of species in function of frequency of rare species observed in each sample, using each collect locality as a sample unity and Bootstrap, which estimates the richness from all the registered species data (Hortal et al., 2006). ${ }^{(34)}$

The similarity in the richness of anuran species between the Bauru region (initials = BUR) and nine regions of the state of São Paulo (Figure 6), dominated by Cerrado and/or Atlantic Forest, was determined through the UPGMA grouping method, applied over matrixes of qualitative similarities of the analyzed studies (Legendre and Legendre, 1998). ${ }^{(35)}$ The nine regions were, with the abbreviations: northwest of the state $=\mathrm{NWS},{ }^{(2,36)}$ Botucatu $=$ BTR,${ }^{(37-38)}$ Lençóis Paulista $=$ LP, ${ }^{(17,39-40)}$ Itirapina $=$ IT, ${ }^{(12-13,41-42)}$ Assis Ecological Station $=$ AES, ${ }^{(14)}$ Caetetus Ecological Station $=$ CES, ${ }^{(43)}$ Jataí Ecological Station $=$ JET, ${ }^{(15)}$ Morro do Diabo State Park $=$ MDST $^{(44)}$ and Furnas do Bom Jesus State Park $=$ FBJSP $^{(16)}$

To make the ordination and grouping analysis, it was used the Past software (version 1.49). ${ }^{(45)}$ The groupings were defined considering the minimal value of $60 \%$ of similarity.

\section{Results}

There were registered 37 species of amphibians, where 36 are from the Anura Order, belonging to six families: Bufonidae (2), Odontophrynidae (2), Hylidae (16), Hylodidade (1), Leptodactylidae (13) and Microhylidae (2), and a cicely from the Siphonopidae family, Siphonops paulensis, from the Gymnophiona Order (Table 2; Figures 2, 3, and 4). This last one was registered by a third party, at the backyard of a house on the urban area of the city, which was included in the list of amphibians species of Bauru region, however, it was only included in the richness data, for being an important occasional registration, outside the localities sampled during the study. The Hylidae family was the most representative, corresponding to $44.45 \%$ of the total number of registered species. 
Table 2 - Species of amphibians registered at the Bauru region, São Paulo.

Class Amphibia Linnaeus, 1758

Order Anura Fischer von Waldheim, 1813

Family Bufonidae Gray, 1825

Rhinella ornata (Spix, 1824)

Rhinella diptycha (Cope, 1862)

Family Odontophrynidae Lynch, 1969

Odontophrynus americanus (Duméril \& Bibron, 1841)

Proceratophrys moratoi (Jim and Caramaschi, 1980)

Family Hylidae Rafinesque, 1815

Dendropsophus elianeae (Napoli and Caramaschi, 2000)

Dendropsophus minutus (Peters, 1872)

Dendropsophus nanus (Boulenger, 1889)

Boana albopunctata (Spix, 1824)

Boana caingua (Carrizo, 1991)

Boana faber (Wied-Neuwied, 1821)

Boana lundii (Burmeister, 1856)

Boana raniceps (Cope, 1862)

Ololygon berthae (Barrio, 1962)

Ololygon hiemalis (Haddad and Pombal, 1987)

Phyllomedusa tetraploidea (Pombal and Haddad, 1992)

Pseudis platensis (Gallardo, 1961)

Scinax fuscomarginatus (Lutz, 1925)

Scinax fuscovarius (Lutz, 1925)

Scinax similis (Cochran, 1952)

Trachycephalus typhonius (Linnaeus, 1758)

Family Hylodidae Günther, 1858

Crossodactylus caramaschii (Bastos and Pombal, 1995)

Family Leptodactylidae Werner, 1896

Leptodactylus chaquensis (Cei, 1950)

Leptodactylus furnarius (Sazima and Bokermann, 1978)

Leptodactylus fuscus (Schneider, 1799)

Leptodactylus labyrinthicus (Spix, 1824)

Leptodactylus latrans (Steffen, 1815)

Leptodactylus mystaceus (Spix, 1824)

Leptodactylus mystacinus (Burmeister, 1861)

Leptodactylus podicipinus (Cope, 1862)

Physalaemus centralis (Bokermann, 1962)

Physalaemus cuvieri (Fitzinger, 1826)

Physalaemus marmoratus (Reinhardt and Lütken, 1862)

Physalaemus nattereri (Steindachner, 1863)

Pseudopaludicola mystacalis (Cope, 1887)

Family Microhylidae Günther, 1858

Chiasmocleis albopunctata (Boettger, 1885)

Elachistocleis cesarii (Miranda-Ribeiro, 1920)

Order Gymnophiona Müller, 1832

Family Siphonopidae Bonaparte, 1850

Siphonops paulensis (Boettger, 1892)

Source: the author. 
Figure 2 - Species of amphibians registered at the Bauru region, São Paulo. $1=$ Rhinella ornata; $2=$ $R$. diptycha; 3 = Odontophrynus americanus; $4=$ Proceratophrys moratoi; $5=$ Dendropsophus elianeae; $6=$ D. minutus; $7=$ D. nanus; $8=$ Boana albopunctata $; 9=$ B. caingua $; 10=$ B. faber; $11=$ B. lundii; $12=$ B. raniceps; $13=$ Ololygon berthae $; 14=$ O. hiemalis; $15=$ Phyllomedusa tetraploidea.
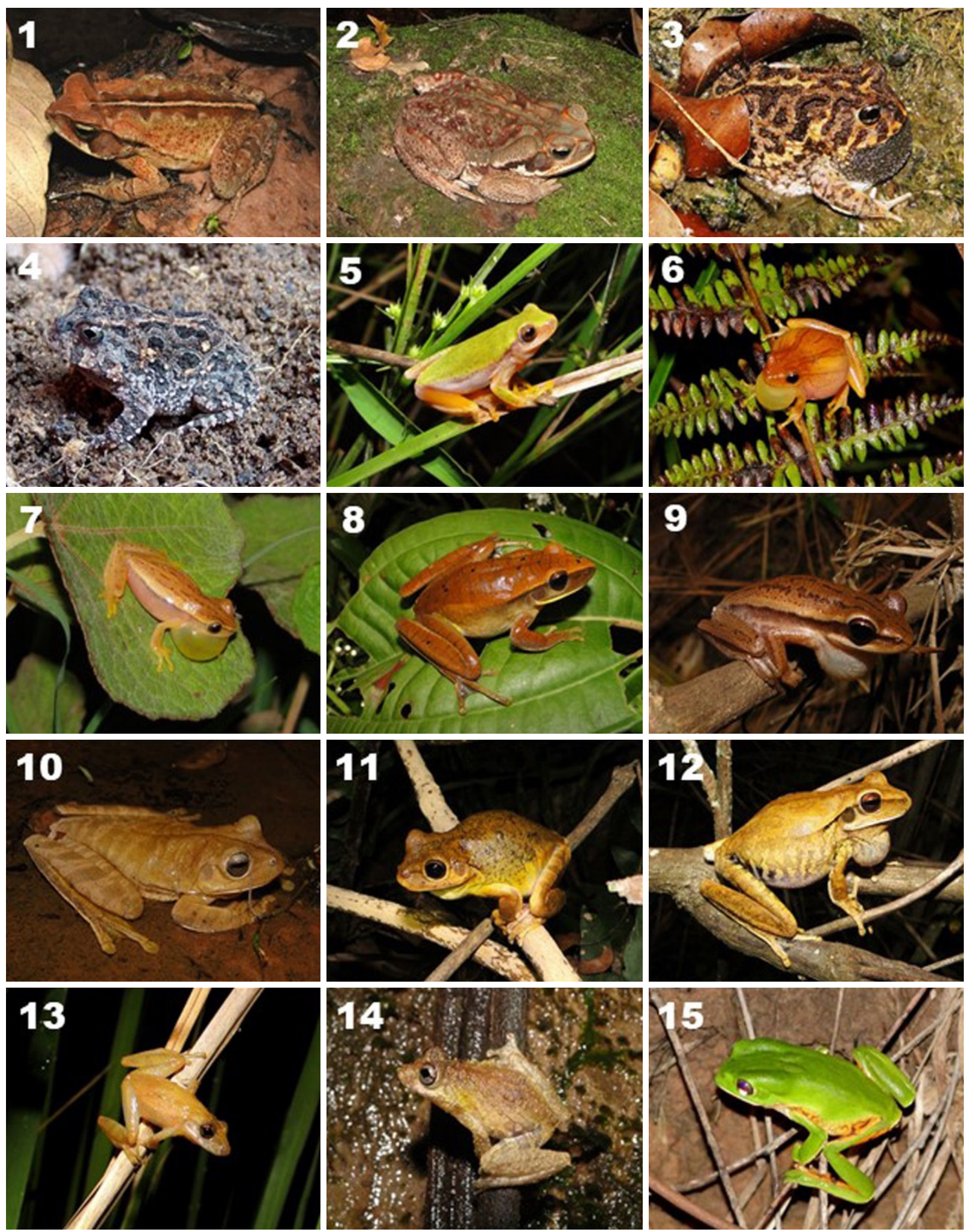

Source: the author. 
Figure 3 - Species of amphibians registered at the Bauru region, São Paulo. $16=$ Pseudis platensis; $17=$ Scinax fuscomarginatus; $18=$ S. fuscovarius; $19=$ S. similis; $20=$ Trachycephalus typhonius; 21 = Crossodactylus caramaschii; $22=$ Leptodactylus chaquensis; $23=$ L. furnarius; $24=$ L. fuscus; $25=$ L. labyrinthicus; $26=$ L. latrans; $27=$ L. mystaceus; $28=$ L. mystacinus; $29=$ L. podicipinus; 30 = Physalaemus centralis.
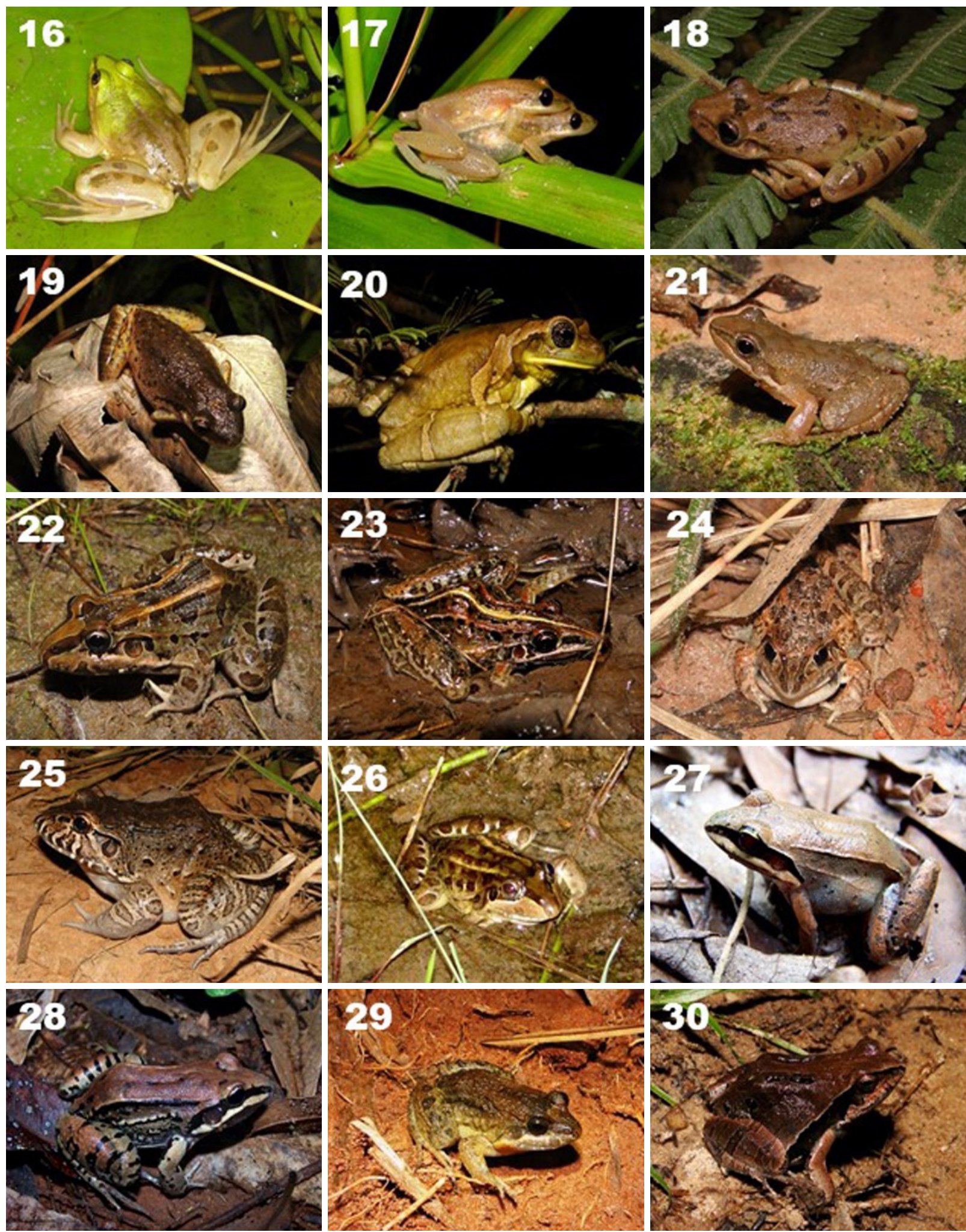

Source: the author. 
Figure 4 - Species of amphibians registered at the Bauru region, São Paulo. $31=$ Physalaemus cuvieri; $32=$ P. marmoratus $; 33=$ P. nattereri; $34=$ Pseudopaludicola mystacalis; $35=$ Chiasmocleis albopunctata; 36 = Elachistocleis cesarii; 37 = Siphonops paulensis.
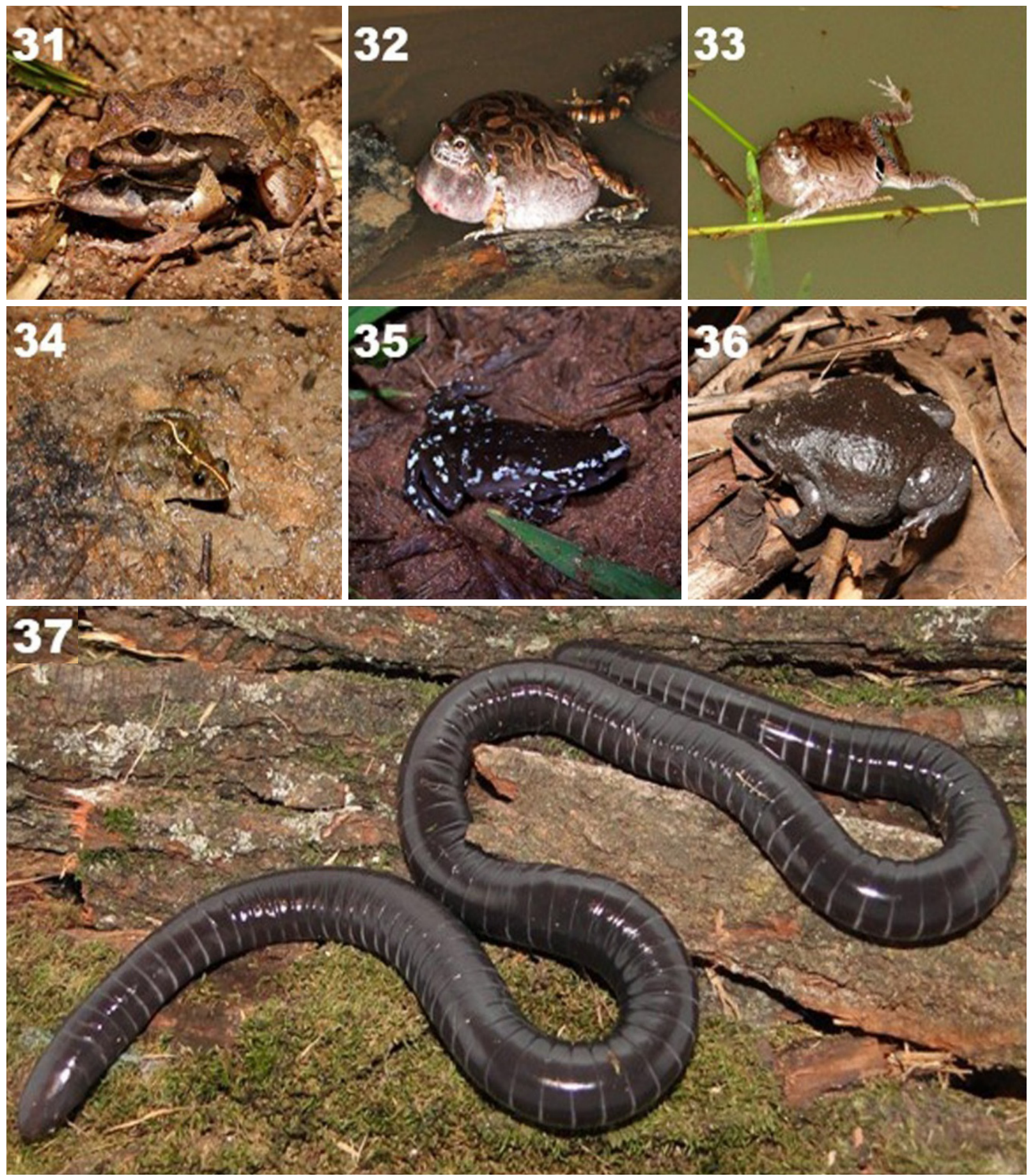

Source: the author.

The richness observed $(\mathrm{n}=36)$ was close to the richness pointed by the Jackknife 1 (36.99) and Bootstrap (36.82) estimators (36.82) and the proximity in the results indicates that the sampling was efficient and representative for the region. The curves of richness stabilized, forming an asymptote, indicating that the observed richness is very close to the real richness (Figure 5). 
Figure 5 - Accumulative curve of species, representing the cumulative richness of amphibians species and the richness observed for the sampling of anurans on the Bauru region, São Paulo.

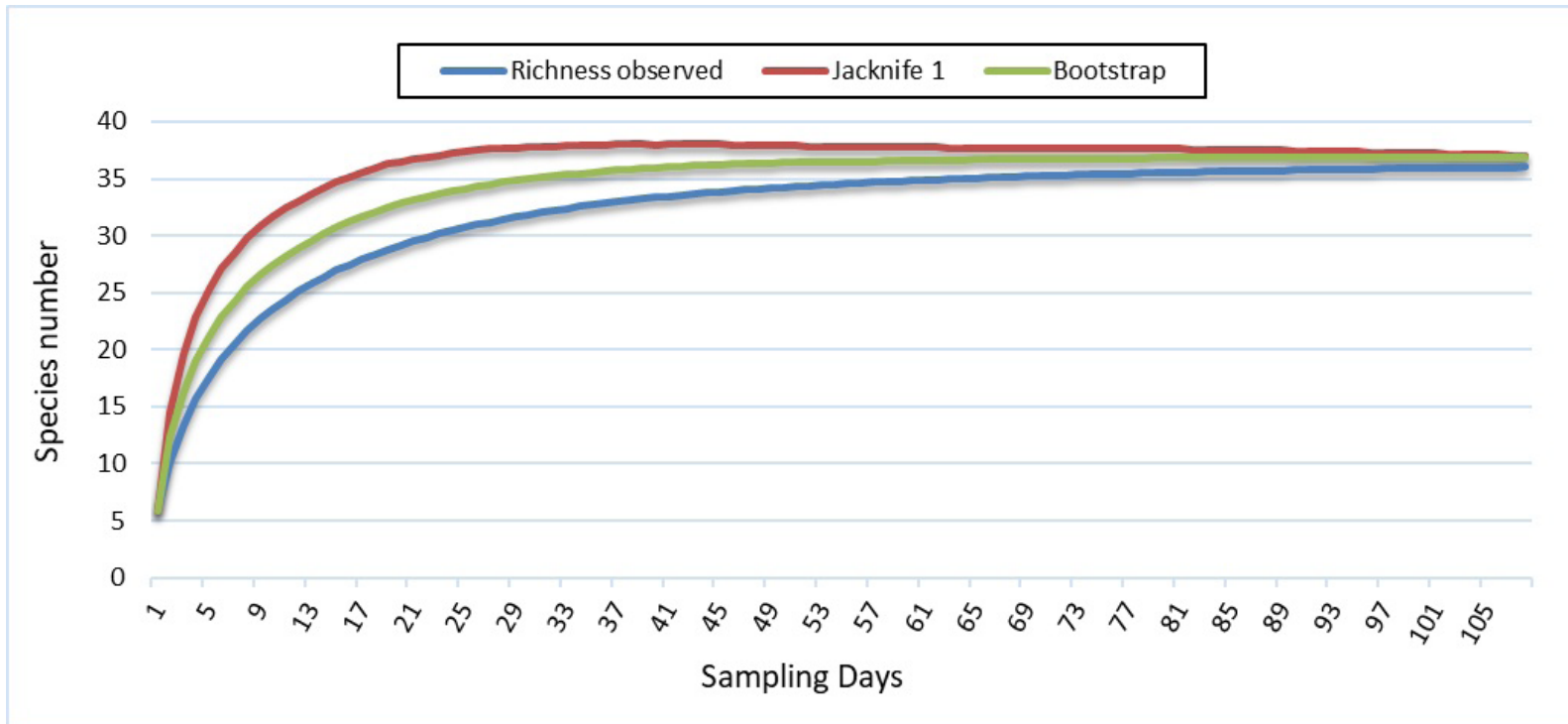

Source: the author.

The species with higher abundance in the $27.84 \%$ of the total registered individuals, with study were Dendropsophus minutus, D. nanus, 800 individuals. Odontophrynus americanus, ProBoana albopunctatus, B. caingua, Scinax fusco- ceratophrys moratoi, Dendropsophus elianae, $B$. marginatus, S. fuscovarius, Physalaemus cuvieri faber, B. raniceps, Crossodactylus caramaschii, and Leptodactylus podicipinus, which represent L. chaquensis and L. latrans were little abundant, $71.12 \%$ of the total registered individuals. With with less than 11 individuals observed along the special attention to D. nanus, which represented study (Table 3).

Table 3 - Abundance of the anuran species registered at the Bauru region. $\mathrm{CA}=$ class of abundance: (1) $<5$; (2) 5-10; (3) 11-20; (4) 21-50; (5) 50-100 and (6) $>100$.

\begin{tabular}{|c|c|c|c|c|c|c|c|c|c|c|}
\hline \multirow{2}{*}{ Species } & \multirow{2}{*}{ CA } & \multicolumn{8}{|c|}{ Localities } & \multirow{2}{*}{ TI } \\
\hline & & 1 & 2 & 3 & 4 & 5 & 6 & 7 & 8 & \\
\hline Rhinella ornata & 4 & 20 & 11 & 4 & 0 & 4 & 3 & 0 & 5 & 47 \\
\hline Rhinella diptycha & 4 & 5 & 4 & 2 & 15 & 0 & 3 & 8 & 1 & 38 \\
\hline Odontophrynus americanus & 2 & 0 & 0 & 0 & 0 & 0 & 10 & 0 & 0 & 10 \\
\hline Proceratophrys moratoi & 2 & 8 & 0 & 0 & 0 & 0 & 0 & 0 & 0 & 8 \\
\hline Dendropsophus elianeae & 2 & 0 & 0 & 2 & 0 & 2 & 1 & 3 & 0 & 8 \\
\hline Dendropsophus minutus & 6 & 21 & 2 & 66 & 56 & 20 & 0 & 53 & 1 & 219 \\
\hline Dendropsophus nanus & 6 & 190 & 110 & 180 & 200 & 0 & 0 & 96 & 30 & 812 \\
\hline
\end{tabular}


Continuation

\begin{tabular}{|c|c|c|c|c|c|c|c|c|c|c|}
\hline Boana albopunctata & 6 & 87 & 30 & 12 & 50 & 5 & 0 & 11 & 50 & 250 \\
\hline Boana caingua & 6 & 40 & 0 & 5 & 5 & 50 & 0 & 0 & 40 & 145 \\
\hline Boana faber & 2 & 0 & 1 & 0 & 0 & 3 & 4 & 1 & 0 & 10 \\
\hline Boana lundii & 4 & 1 & 0 & 0 & 0 & 20 & 9 & 0 & 7 & 40 \\
\hline Boana raniceps & 3 & 0 & 0 & 0 & 4 & 0 & 0 & 5 & 0 & 11 \\
\hline Ololygon berthae & 3 & 0 & 0 & 10 & 4 & 0 & 0 & 0 & 0 & 16 \\
\hline Ololygon hiemalis & 3 & 0 & 0 & 0 & 0 & 0 & 0 & 0 & 17 & 20 \\
\hline Phyllomedusa tetraploidea & 4 & 0 & 0 & 0 & 0 & 16 & 0 & 2 & 1 & 22 \\
\hline Pseudis platensis & 4 & 0 & 0 & 0 & 13 & 0 & 0 & 5 & 0 & 21 \\
\hline Scinax fuscomarginatus & 6 & 0 & 40 & 10 & 35 & 0 & 0 & 65 & 0 & 155 \\
\hline Scinax fuscovarius & 6 & 35 & 1 & 46 & 35 & 15 & 11 & 30 & 1 & 178 \\
\hline Scinax similis & 5 & 2 & 0 & 10 & 61 & 0 & 0 & 4 & 0 & 82 \\
\hline Trachycephalus typhonius & 4 & 0 & 5 & 0 & 10 & 0 & 0 & 20 & 2 & 40 \\
\hline Crossodactylus caramaschii & 1 & 0 & 0 & 0 & 2 & 2 & 0 & 0 & 0 & 5 \\
\hline Physalaemus centralis & 3 & 0 & 0 & 2 & 2 & 0 & 0 & 8 & 0 & 14 \\
\hline Physalaemus cuvieri & 6 & 26 & 8 & 17 & 48 & 9 & 0 & 35 & 10 & 157 \\
\hline Physalaemus marmoratus & 3 & 0 & 0 & 10 & 7 & 0 & 0 & 0 & 0 & 19 \\
\hline Physalaemus nattereri & 4 & 1 & 0 & 9 & 0 & 5 & 0 & 10 & 1 & 28 \\
\hline Leptodactylus chaquensis & 1 & 1 & 0 & 0 & 0 & 0 & 0 & 2 & 0 & 4 \\
\hline Leptodactylus furnarius & 4 & 0 & 0 & 10 & 0 & 0 & 0 & 10 & 0 & 22 \\
\hline Leptodactylus fuscus & 5 & 13 & 4 & 8 & 18 & 3 & 0 & 35 & 2 & 87 \\
\hline Leptodactylus labyrinthicus & 3 & 1 & 1 & 1 & 0 & 0 & 0 & 8 & 0 & 13 \\
\hline Leptodactylus latrans & 1 & 0 & 0 & 1 & 0 & 0 & 0 & 0 & 0 & 2 \\
\hline Leptodactylus mystaceus & 3 & 0 & 0 & 0 & 10 & 1 & 0 & 4 & 0 & 17 \\
\hline Leptodactylus mystacinus & 5 & 10 & 5 & 10 & 10 & 15 & 0 & 20 & 1 & 74 \\
\hline Leptodactylus podicipinus & 6 & 10 & 30 & 6 & 101 & 0 & 0 & 5 & 0 & 158 \\
\hline Pseudopaludicola mystacalis & 5 & 0 & 0 & 0 & 50 & 0 & 0 & 15 & 0 & 69 \\
\hline Chiasmocleis albopunctata & 3 & 0 & 0 & 0 & 11 & 0 & 0 & 2 & 0 & 16 \\
\hline Elachistocleis cesarii & 5 & 5 & 0 & 2 & 34 & 3 & 0 & 43 & 8 & 99 \\
\hline
\end{tabular}

Source: the author.

The peak activity of anurans vocalization vocalization activity during the whole year. Howwas concentrated during the rainy season, between ever, the peak activity of these species was concenthe months September and February (Table 4). trated during the rainy period. $R$. ornata and O. hieOnly D. minutus, B. caingua and B. lundii showed malis showed peak activity during the dry season. 
Table 4 - Temporal distribution of the anuran species registered at the Bauru region. The blank spaces means that the species was not detected in the period.

= in vocalization activity; $\square$ not in vocalization activity.

\begin{tabular}{|c|c|c|c|c|c|c|c|c|c|c|c|c|}
\hline Species & $\mathbf{J}$ & $\mathbf{F}$ & $\mathbf{M}$ & $\mathbf{A}$ & $\mathbf{M}$ & $\mathbf{J}$ & $\mathbf{J}$ & $\mathbf{A}$ & $\mathbf{S}$ & $\mathbf{O}$ & $\mathbf{N}$ & D \\
\hline \multicolumn{13}{|l|}{ Rhinella ornata } \\
\hline \multicolumn{13}{|l|}{ Rhinella diptycha } \\
\hline \multicolumn{13}{|l|}{ Odontophrynus americanus } \\
\hline \multicolumn{13}{|l|}{ Proceratophrys moratoi } \\
\hline \multicolumn{13}{|l|}{ Dendropsophus elianeae } \\
\hline \multicolumn{13}{|l|}{ Dendropsophus minutus } \\
\hline \multicolumn{13}{|l|}{ Dendropsophus nanus } \\
\hline \multicolumn{13}{|l|}{ Boana albopunctatus } \\
\hline \multicolumn{13}{|l|}{ Boana caingua } \\
\hline \multicolumn{13}{|l|}{ Boana faber } \\
\hline \multicolumn{13}{|l|}{ Boana lundii } \\
\hline \multicolumn{13}{|l|}{ Boana raniceps } \\
\hline \multicolumn{13}{|l|}{ Ololygon berthae } \\
\hline \multicolumn{13}{|l|}{ Ololygon hiemalis } \\
\hline \multicolumn{13}{|l|}{ Phyllomedusa tetraploidea } \\
\hline \multicolumn{13}{|l|}{ Pseudis platensis } \\
\hline \multicolumn{13}{|l|}{ Scinax fuscomarginatus } \\
\hline \multicolumn{13}{|l|}{ Scinax fuscovarius } \\
\hline \multicolumn{13}{|l|}{ Scinax similis } \\
\hline \multicolumn{13}{|l|}{ Trachycephalus typhonius } \\
\hline \multicolumn{13}{|l|}{ Crossodactylus caramaschii } \\
\hline \multicolumn{13}{|l|}{ Physalaemus centralis } \\
\hline \multicolumn{13}{|l|}{ Physalaemus cuvieri } \\
\hline \multicolumn{13}{|l|}{ Physalaemus marmoratus } \\
\hline Physalaemus nattereri & & & & & & & & & & & & \\
\hline Leptodactylus chaquensis & & & & & & & & & & & & \\
\hline Leptodactylus furnarius & & & & & & & & & & & & \\
\hline Leptodactylus fuscus & & & & & & & & & & & & \\
\hline Leptodactylus labyrinthicus & & & & & & & & & & & & \\
\hline Leptodactylus latrans & & & & & & & & & & & & \\
\hline Leptodactylus mystaceus & & & & & & & & & & & & \\
\hline Leptodactylus mystacinus & & & & & & & & & & & & \\
\hline Leptodactylus podicipinus & & & & & & & & & & & & \\
\hline Pseudopaludicola mystacalis & & & & & & & & & & & & \\
\hline Chiasmocleis albopunctata & & & & & & & & & & & & \\
\hline Elachistocleis cesarii & & & & & & & & & & & & \\
\hline
\end{tabular}

Source: the author. 
Among the aquatic environments occupied by the anurans at the Bauru region, only four species were exclusive to water bodies inside the forest: B. lundii, O. hiemalis, C. caramaschii and $L$. mystaceus, which represented $11 \%$ of the registered species. The other remained divided between species that used exclusively, during the vocalization activity, water bodies on open areas (44.5\%) and species that used water bodies inside the forest and on open areas $(44.5 \%)$.

In comparison to other regions of the state, situated in areas of Cerrado and Atlantic Forest, Bauru resemble with the northwestern region of the state with $0.72 \%$ in species composition (Figure 6 ).

Figure 6 - Similarity between the Bauru region and nine other regions of the state of São Paulo, based on the species composition. Abbreviations: northwest of the state $=$ NWS; Botucatu region $=\mathrm{BTR}$; Lençóis Paulista = LP; Itirapina = IT; Assis Ecological Station = AES; Caetetus Ecological Station $=$ CES; Jataí Ecological Station $=$ JET; Morro do Diabo State Park = MDST; Furnas do Bom Jesus State Park = FBJSP.

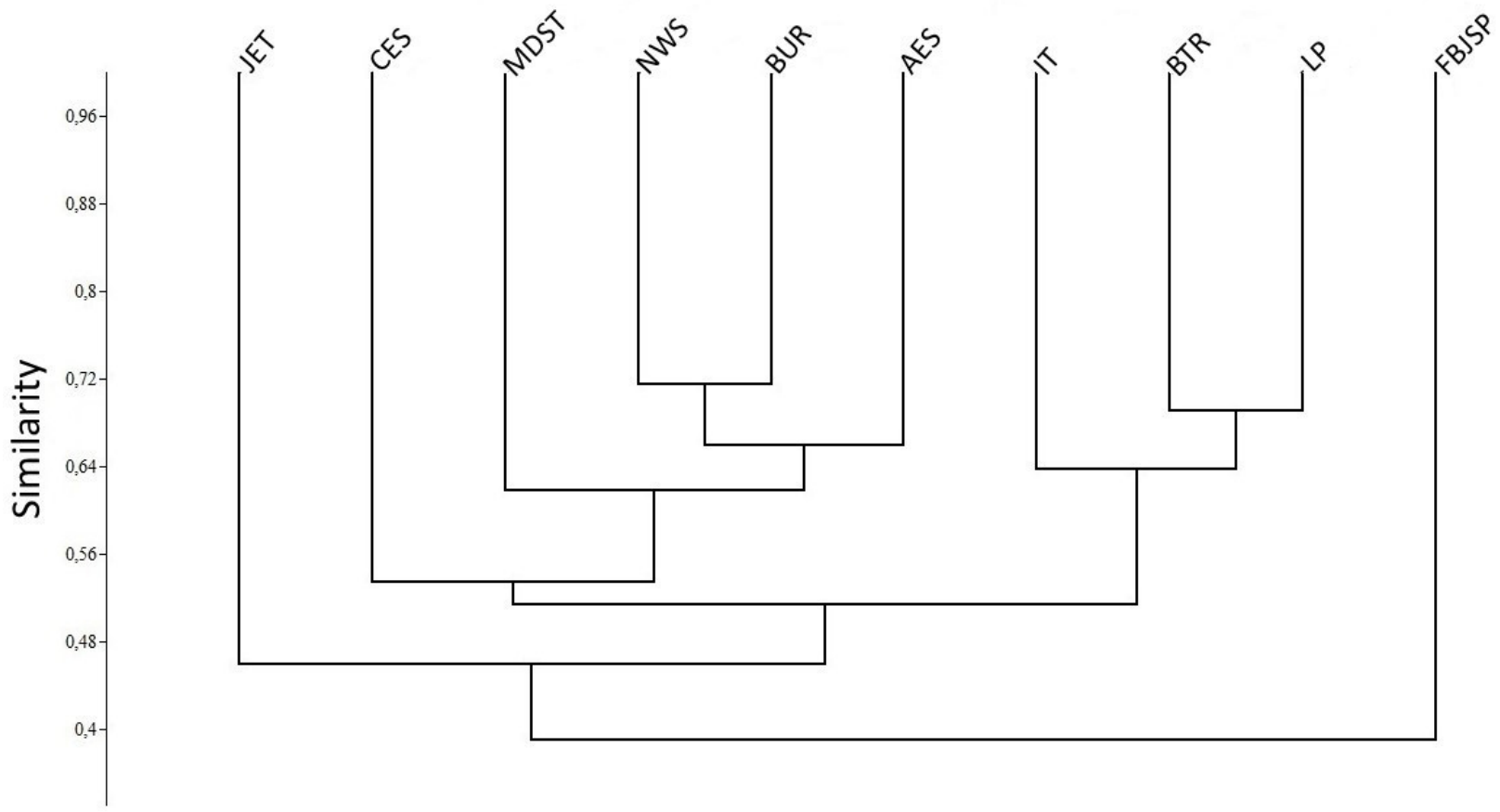

Source: the author.

\section{Discussion}

The amphibians of the Bauru region represent $15.61 \%$ of the species of the state of São Paulo. ${ }^{(2-3)}$ From the 14 amphibians families occurring in the state, seven were registered at the Bauru region.

Taking into consideration the occurrence of the species in the state of São Paulo, on the Bauru region there was a predominance of species that presented distribution on the center-western region, with 16 of the 37 registered species. Twelve have occurred in all of the state, eight have occurred in the center-eastern region and only P. moratoi have occurred in the central area of the state. There were interesting records of $L$. chachensis, widening the species' area of occurrence to the central region of the state, and from C. caramaschii, that presented distribution mainly to the eastern region of the state, in areas of tropical rain forest, and it was registered in this study in a Cerrado area.

Taking into consideration the type of occupied phytophysiognomy, there was a predominance of generalist species (species with wide geographic 
distribution and that occupying open and forest environments), with 23 that have been registered on the main existent vegetable formations of the state (Cerrado, Semideciduous Seasonal Forest and Tropical Rainforest). Only P. moratoi is endemic to the Cerrado biome. The other species registered in the study have occurred in more than um type of vegetable formation, between areas of Cerrado and Atlantic Forest.

Among the registered species, Ololygon hiemalis is endemic to the state of São Paulo and Proceratophrys moratoi shows restrict occurrence to Cerrado dominated areas. ${ }^{(46-47)}$ Ololygon hiemalis occurs only on streams at Atlantic Forest areas, ${ }^{(37,39,43,48-50)}$ however, in this work, Ololygon hiemalis was registered in a stream situated inside a Cerradão fragment, being the first register of the species to this biome.

Proceratophrys moratoi is cited in the National List of Brazilian Fauna Species in Threat of Extinction at the category "in danger". ${ }^{(29)}$ The species was included at the List of Threatened Species of the State of São Paulo, ${ }^{(30)}$ however, thanks to the new registrations of $P$. moratoi populations, ${ }^{(46-47)}$ it has been removed from the list. In the IUCN Red List of Threatened Species, is appointed that Critically Endangered. ${ }^{(31)}$ It is important to mention that the species disappearance from the type locality, by anthropogenic environmental changes. ${ }^{(51)}$

The abundance indexes resemble those of the Botucatu region, where the most abundant species were also P. cuvieri, D. nanus, S. fuscovarius, D. minutus and B. albopuncatus, differentiating regarding $B$. caingua and L. podicipinus, that presented the lowest abundance regarding the Bauru region. ${ }^{(37)}$ Regarding the northwestern region of the state, ${ }^{(36)}$ it was observed that there is also great resemblance considering the most abundant species, because $D$. minutus, D. nanus, $S$. fuscomarginatus, $P$. cuvieri and L. podicipinus were abundant, as in the Bauru region. However, species like D. elianeae and $P$. nattererii, which showed high abundance to the northwestern region of the state, weren't abundant in the Bauru region.
The activity pattern of the amphibian species is also observed for all the central-western region of the state, that presents two well defined seasons, one hot and rainy and other cold and dry, as in the Bauru region (Table 4). The Bauru region showed an equal number of species as the northwestern region of the state. ${ }^{(2,36)}$ However, it showed a lower richness in comparison to the Botucatu region, which has 52 species of amphibians. It is possible to observe that the farthest the region is from the east of the state of São Paulo, lower or absent is the number of species with peak activity during the dry season. The Botucatu region shows five species with reproductive peak activity during the coldest and driest period of the year. ${ }^{(37)}$ In this study, there were registered only two species with peak activity during this period. But on the northwestern region, there are no registrations of species with reproductive peak activity during the driest period of the year. $^{(28,52)}$ This difference occurs mainly because of the relative air humidity indexes, that get to very low levels during the driest period of the year in the central-western region of the state, and that possibly influence the occurrence of species with the activity concentrated during this period of the year.

At the Botucatu region, there is a higher number of forest exclusive species, with 6 species (Haddadus binotatus, Hyalinobatrachium uranoscopum, Proceratophrys boiei, Bokermannohyla izecksohni, Ololygon hiemalis and Crossodactylus caramaschii). ${ }^{(37)}$ But on the northwesten region there is only the registration of two species (Boana lundii, Leptodactylus mystaceus) associated to water bodies inside or at the border of the forest during the vocalization activity. ${ }^{(36)}$ The Botucatu's forest exclusive species are typical to humid physiognomies of Atlantic Forest, which shows a higher influence of this biome over the Botucatu region, in comparison to the Bauru region and state's northwestern regions.

The difference and resemblance of the composition of amphibians (Figure 3) among other sampled regions of the state of São Paulo are due to the environmental heterogeneity, which is higher 
at the Botucatu region, ${ }^{(37,50)}$ and similar between the northwestern ${ }^{(52)}$ and Bauru region. Other factors that influence a lot on the richness difference among these regions are: climate, level of degradation and fragmentation, relief and phytophysiognomy. According to Ab'Sáber, ${ }^{(53)}$ the temperature indexes are slightly crescents from the centralsouth to the north and northwest and from east to the west of the state of São Paulo. Regarding the rainfall, the west tablelands of the state presented the lowest indexes of rainfall (1,000 to $1,100 \mathrm{~mm}$ annually), while the other extensions of the interior highlands present precipitations that vary from 1,300 to $1,800 \mathrm{~mm}$ annually.

The Bauru and state's northwestern regions show higher temperatures and lower rainfall indexes, especially during the dry season, ${ }^{(52,53,55)}$ diverging the Botucatu region, which has milder temperatures. ${ }^{(54)}$ The tropical climates of humid summer and dry winter (Aw) has its dominant area in a large zone from the extreme northwest and north of the state, exactly where there is made a more direct transition to the peculiar climate types and huge areas of Central Brazil in the "Cerrado's Domain". ${ }^{(24)}$ The original vegetable formation was constituted of Semideciduous Seasonal Forest in the northwestern region, which was practically substituted by areas of pasture. ${ }^{(52)}$ The vegetation of Bauru and state's northwestern region's is characterized by Forest Savannah (Cerradão) and Semideciduous Seasonal Forest fragments ${ }^{(4)}$ diverging the Botucatu region, that is covered by different vegetable formations, like broadleaf tropical forest, slope tropical forest, slope mesophilic semideciduous forest and different degrees of Cerrado. ${ }^{(54)}$

According to analysis made by Vasconcelos et al. ${ }^{(56)}$ the species richness is associated to the climate and altitude, and the factor the directly influences the richness of species of a region is the annual rainfall index. The precipitation and air's relative humidity are deeply related to the amphibians' biology, which rely on these factors for reproduction and survival. ${ }^{(56)}$ For regions under the dominance of the Cerrado and Semidecidous
Seasonal Forest, the species' richness is also deeply associated to the annual rainfall concentration. ${ }^{(56)}$ The factors pointed out by Vasconcelos et al., ${ }^{(56)}$ possibly regulate the occurrence of amphibian species in the Bauru region. At the Bauru region there are those two vegetable formations, which conclude that the annual rainfall affects the presence of the amphibians' presence in the region.

These morphoclimatic differences between Bauru and the other regions influence a lot in the species' composition of each place. Especially the temperature and humidity factors, that allow or not the occurrence of a certain species in a certain region. This happens because of the differences in the adaptive conditions and environmental plasticity of each species, regarding the habitat occupied by the larva and the adult and regarding the reproductive mode and its biological needs.

The amphibians' community of the Bauru region shows its own characteristics and is adapted to the morphoclimatic conditions, the environmental heterogeneity and the conservation of the natural resources that reflect directly on the composition, abundance and spatial and temporal distribution pattern of the amphibian species present at the region.

The richness of amphibians of the Bauru region is significant for the state of São Paulo and the region contributes with the maintenance of environments with conditions for the occurrence of Proceratophrys moratoi, which is considered in threat of extinction. This study contributed with the filling gap on the amphibian knowledge of the state of São Paulo, because the Bauru region is situated in an area appointed by Rossa-Feres et al. ${ }^{(3)}$ as with little knowledge of the anuran's fauna.

\section{Acknowledgements}

I want to thank the Conselho Nacional de Desenvolvimento Científico e Tecnológico - CNPq (\#140473/2011-4) for the financial support and Dr. Anderson da Silva Lucindo for the help in the elaboration of the statistical analysis and for the critical reading of the manuscript. 


\section{References}

1 Segalla MV, Caramaschi U, Cruz CAG, Grant T, Haddad CFB, Garcia PCA, et al. Brazilian amphibians: list of species. Herpetol Bras. 2016 Jul;5(2):34-6.

2 Silva FR, Prado VHM, Rossa-Feres DC. Amphibia, Anura, Hylidae, Dendropsophus melanargyreus (Cope, 1887): Distribution extension, new state record and geographic distribution map. Check List 2010 Aug;6(3):402-4. doi: 10.15560/6.3.402.

3 Rossa-Feres DC, Sawaya RJ, Faivovich J, Giovanelli JGR, Brasileiro CA, Schiesari L, et al. Anfíbios do Estado de São Paulo, Brasil: Conhecimento Atual e Perspectivas. Biota Neotrop. 2011 Jan;11(Supl.1):47-66. doi: 10.1590/S167606032011000500004.

4 Siqueira MF, Durigan G. Modelagem da distribuição geográfica de espécies lenhosas de cerrado no Estado de São Paulo. Rev Bras Bot. 2007. Apr;30(2):233-43. doi: 10.1590/S010084042007000200008 .

5 Ratter JA, Ribeiro JF, Bridgewater S. The Brazilian cerrado vegetation and threats to its biodiversity. Ann Bot. 1997 Sep;80(3):223-30. doi: 10.1006/anbo.1997.0469.

6 Klink CA, Machado RB. Conservation of the Brazilian cerrado. Conserv Biol. 2005 Jun;19 (3): 707-13. doi: 10.1111/j.1523-1739.2005. 00702.x.

7 Bitencourt MD, Mendonça RR. Viabilidade de conservação dos remanescentes de cerrado no estado de São Paulo. São Paulo: Annablume; 2004.

8 Ribeiro MC, Metzger JP, Martensen AC, Ponzoni FJ, Hirota MM. The Brazilian Atlantic Forest: how much is left, and how is the remaining forest distributed? Implications for conservation. Biol Conserv. 2009 Jun;142(6):1141-53. doi: 10.1016/j.biocon.2009.02.021.

9 Valdujo PH, Silvano DL, Colli G, Martins M. Anuran species composition and distribution patterns in Brazilian Cerrado, a Neotropical Hotspot. South Am J Herpetol. 2012 Aug;7(2):6378. doi: 10.2994/057.007.0209.
10 Haddad CFB, Toledo LF, Cynthia PAP, Loebmann D, Gasparini JL, Sazima I. Guia dos Anfíbios da Mata Atlântica: diversidade e distribuição. São Paulo: Anolisbooks; 2013.

11 Bernarde PS, Kokubum MNC. Anurofauna do município de Guararapes, estado de São Paulo, Brasil (Amphibia: Anura). Acta Biol. Leopoldensia. 1999 Jun;21(1):89-97.

12 Zina J, Ennser J, Pinheiro SCP, Haddad CFB, Toledo LF. Taxocenose de anuros de uma mata semidecídua do interior do Estado de São Paulo e comparações com outras taxocenoses do Estado, sudeste do Brasil. Biota Neotrop. 2007 May;7(2):49-57. doi: 10.1590/S1676-0603200 7000200005 .

13 Brasileiro CA, Sawaya RJ, Kiefer MC, Martins M. Amphibians of an open cerrado fragment in southeastern Brazil. Biota Neotrop. 2005 Jan;5(2): 93-109. doi: 10.1590/S1676-06032005000300006.

14 Araujo CO, Almeida-Santos SM. Herpetofauna de um remanescente de cerrado no estado de São Paulo, sudeste do Brasil. Biota Neotrop. 2011 Jul;11(3):47-62. doi: 10.1590/S1676-060 32011000300003.

15 Prado VHM, Silva FR, Dias NYN, Pires JSR, Rossa-Feres DC. Anura, Estação Ecológica de Jatai, São Paulo state, southeastern Brazil. Check List. 2009 Aug;5(3):495-502.

16 Araujo CO, Condez TH, Sawaya RJS. Anfíbios Anuros do Parque Estadual das Furnas do Bom Jesus, sudeste do Brasil, e suas relações com outras taxocenoses no Brasil. Biota Neotrop. 2009 Apr;9(2):77-98. doi: 10.1590/S167606032009000200007.

17 Maffei F, Ubaid FK, Jim J. Anurofauna em área de cerrado aberto no município de Borebi, estado de São Paulo, Sudeste do Brasil: uso do habitat, abundância e variação sazonal. Biota Neotrop. 2011 Jun;11(2):221-33. doi: 10.1590/ S1676-06032011000200023.

18 Araujo CO, Corrêa DT, Santos SMA. Anuros da Estação Ecológica de Santa Bárbara, um remanescente de formações abertas de Cerrado no estado de São Paulo. Biota Neotrop. 2013 Sep;13(3):230-40. doi: doi.org/10.1590/S167606032013000300026. 
19 Araujo CO, Almeida-Santos SM. Composição, riqueza e abundância de anuros em um remanescente de Cerrado e Mata Atlântica no estado de São Paulo. Biota Neotrop. 2013 Mar;13 (1):265-75. doi: doi.org/10.1590/S1676-06032 013000100026 .

20 Costa WP, Almeida SC, Jim J. Anurofauna em uma área na Depressão Periférica no centrooeste do estado de São Paulo, Brasil. Biota Neotrop. 2013 Jun;13(2):163-74. doi: 10.1590/ S1676-06032013000200015.

21 Maffei F, Nascimento BTM, Moya GM, Donatelli RJ. Anurans of the Agudos and Jaú municipalities, state of São Paulo, Southeastern Brazil. Check List. 2015 Apr;11(3):1645. doi: 10.15560/11.3.1645.

22 Benício RA, Silva FR. Amphibians of Vassununga State Park, one of the last remnants of semideciduous Atlantic Forest and Cerrado in northeastern São Paulo state, Brazil. Biota Neotrop. 2017 Mar;17(1): e20160197. doi: 10.1590/1676-0611-bn-2016-0197.

23 Araujo CO. Hepetofauna da Estação Ecológica de Bauru, um fragmento de Mata Atlântica no Estado de São Paulo. Revista do Instituto Florestal. 2017 Jun;29:71-89. doi: 10.24278/21785031.201729105.

24 Peel MC, Finlayson BL, McMahon TA. Updated world map of the Köppen-Geiger climate classification. Hydrol Earth Syst Sci. 2007 Oct;11:1633-44. doi: 10.5194/hess-111633-2007.

25 Ab'Sáber AN. A terra paulista. Boletim Paulista de Geografia. 1956 Jul;23:5-38.

26 Instituto de Pesquisas Meteorológicas Estação meteorológica de Bauru, São Paulo, Brazil. [Internet]. São Paulo: Universidade Estadual Paulista "Júlio de Mesquita Filho"; 2017 [citado 2017 jun 19]. Disponível em:http:// www.ipmet.unesp.br/index 2.php?menu esq1 $=$ \&abre=ipmet_html/estacao/historico.php

27 Heyer WR, Donnely MA, McDiarmid RW, Hayek LC, Foster MS. Measuring and Monitoring Biological Diversity - Standart Methods for Amphibians. Washington: Smithsonian Institution Press; 1994.
28 Vasconcelos TS, Rossa-Feres DC. Diversidade, distribuição espacial e temporal de anfíbios anuros (Amphibia, Anura) na região noroeste do estado de São Paulo, Brasil. Biota Neotrop. 2005 Aug;5(2):137-50. doi: 10.1590/S167606032005000300010 .

29 Instituto Chico Mendes de Conservação da Biodiversidade. As Listas das Espécies da Fauna Brasileira Ameaçadas de Extinção vigentes (Portarias MMA no 444/2014 e n n $^{\circ} 45 / 2014$ ). [Internet]. 2014. [citado 2020 jul 18]. Disponível em: http://www.icmbio.gov.br/portal/ biodiversidade/fauna-brasileira/lista-de-especies.html

30 São Paulo (SP). Decreto Estadual n ${ }^{0} 63.853$ de 27 de novembro de 2018. Declara as espécies da fauna silvestre no Estado de São Paulo regionalmente extintas, as ameaçadas de extinção, as quase ameaçadas e as com dados insuficientes para avaliação, e dá providências correlatas. [Internet]. 2018 [citado 2020 jul 18]. Disponível em: https://www.al.sp.gov. br/repositorio/legislacao/decreto/2018/decreto-63853-27.11.2018.html

31 Cruz CAG, Caramaschi U. Proceratophrys moratoi: The IUCN Red List of Threatened Species 2004: e.T57192A11585663. [Internet]. 2004. [cited 2020 jul 18] Available at: https:// dx.doi.org/10.2305/IUCN.UK.2004.RLTS. T57192A11585663.en

32 Frost DR, American Museum of Natural History. Amphibian Species of the World: an Online Reference. [Internet]. 2020. [cited 2020 jul 18] Available at: https://amphibiansoftheworld. amnh.org/index.php

33 Colwell RK. EstimateS: statistical estimation of species richness and shared species from samples. Version 9.1.0. [Internet]. 2016 [cited 2020 jul 18] Available at http://viceroy.eeb. uconn.edu/estimates/

34 Hortal J. Borges PAV, Gaspar C. Evaluating the performance of species richness estimators: sensitivity to sample grain size. Journal of Animal Ecology 2006 Jan;75:274-87. doi: 10.1111/j.1365-2656.2006.01048.x.

35 Legendre P, Legendre L. Numerical Ecology. Oxford: Elsevier Science; 1998. 
36 Provete DB, Garey MV, Silva FR, Rossa-Feres DC. Anurofauna do noroeste paulista: lista de espécies e chave de identificação para adultos. Biota Neotrop. 2011 Apr;11(2):377-91. doi: 10.1590/S1676-06032001000200036.

37 Almeida SC. Ecologia de Lithobates catesbeianus (SHAW, 1802) e relações com os anfíbios da região de Botucatu, SP (Amphibia, Anura). [tese]. Botucatu (SP): Universidade Estadual Paulista; 2010.

38 Lopes PC. Distribuição e abundância de anfíbios e répteis neotropicais em paisagem silvicultural em São Paulo, Brasil. [dissertação]. Piracicaba (SP): Universidade de São Paulo; 2010.

39 Rolim DC. Bioecologia de Odontophrynus moratoi (Amphibia, Anura, Cycloramphidae). [dissertação]. Botucatu (SP): Universidade Estadual Paulista; 2009.

40 Maffei F. Diversidade e uso do habitat de comunidades de anfíbios anuros em Lençóis Paulista, Estado de São Paulo. [dissertação]. Botucatu (SP): Universidade Estadual Paulista; 2010.

41 Brasileiro CA, Martins IA, Jim J. Amphibia, Anura, Cycloramphidae, Odontophrynus moratoi: Distribution extension and advertisement call. Check List 2008 Oct;4(4):382-5. doi: 10.15560/4.4.382.

42 Sabbag AF, Zina J. Anurofauna de uma mata ciliar no município de São Carlos, estado de São Paulo, Brasil. Biota Neotrop. 2011 Oct;11 (3):179-88. doi: 10.1590/S1676-06032011000 300015 .

43 Brassaloti RA, Rossa-Feres DC, Bertoluci J. Anurofauna da Floresta Estacional Semidecidual da Estação Ecológica dos Caetetus, sudeste do Brasil. Biota Neotrop. 2010 Feb;10(1):27591. doi: 10.1590/S1676-06032010000100 024.

44 Santos TG, Vasconcelos TS, Rossa-Feres DC, Haddad CFB. Anurans of a seasonally dry tropical Forest: Morro do Diabo State Park, São Paulo state, Brazil. J. Nat. Hist. 2009 Jan;43: 973-93. doi: 10.1080/00222930802702498.
45 Hammer O, Harper DAT, Ryan PD. PAST: Paleontological Statistics Software Package for education and data analysis. Palaeontol Electronica 2001 May;4(1):1-9.

46 Rolim DC, Martinez RAM, Almeida SC, Ubaid FK, Maffei F, Jim J. Amphibia, Anura, Cycloramphidae, Proceratophrys moratoi (Jim and Caramaschi, 1980): Distribution extension and new altitudinal record in state of São Paulo, Brazil. Check List. 2010 Nov;6(4):5768. doi: 10.15560/6.4.576.

47 Martins LB, Giaretta AA. Advertisement Calls of Two Species of Proceratophrys (Anura: Odontophrynidae) from Minas Gerais, Brazil, with Comments on their Distribution, Taxonomy and Conservation Status. South Am J Herpetol. 2012 Dec;7(3):203-12. doi: 10.2994/057.007. 0302 .

48 Haddad CFB, Prado CPA. Reproductive modes in frogs and their unexpected diversity in the Atlantic forest of Brazil. Bio Science. 2005 Mar;55(3):207-17. doi: 10.1641/ 0006-3568(2005)055[0207:RMIFAT]2.0. $\mathrm{CO} ; 2$.

49 Jim J. Aspectos ecológicos dos anfíbios registrados na região de Botucatu, São Paulo. [tese]. São Paulo (SP): Universidade de São Paulo; 1980.

50 Jim J. Distribuição altitudinal e estudo de longa duração de anfíbios da região de Botucatu, estado de São Paulo. [tese de Livre-Docência]. Botucatu (SP): Universidade Estadual Paulista; 2002.

51 Rolim DC, Almeida, SC. Disappearance of Proceratophrys moratoi in its type locality by anthropogenic environmental changes. Semina: Ciências Biológicas e da Saúde. 2017 Jul;38 (2):119-28. doi: 10.5433/1679-0367.2017v38 n2p119.

52 Santos TG, Rossa-Feres DC, Casatti L. 2007. Diversidade e distribuição espaço-temporal de anuros em região com pronunciada estação seca no sudeste do Brasil. Iheringia Ser. Zool. 2007 Mar;97(1):37-49. doi: 10.1590/S003747212007000100007. 
53 Ab'Sáber NA. São Paulo: o chão, o clima e as águas. In: Freitas MJV, Pimentel O, editores. São Paulo: espírito, povo, instituições. São Paulo: Pioneira; 1968. p. 13-27.

54 Fundação Florestal. Plano de Manejo da Área de Proteção Ambiental Corumbataí, Botucatu e Tejupá - Perímetro Botucatu. [Internet]. São Paulo: Fundação Florestal; 2011 [citado 2020 jul 18]. Disponível em: http://arquivos. ambiente.sp.gov.br/fundacaoflorestal/2016/03/ Volume-1-Diagn\%C3\%B3stico.pdf

55 Barcha SF, Arid FM. Estudo da evapotranspiração na região Norte Ocidental do Estado de São Paulo. RevCiêncFacCiênc Letras Votuporanga. 1971 1:97-122.

56 Vasconcelos TS, Santos TG, Haddad CFB, Rossa-Feres DC. Climatic variables and altitude as predictors of anuran species richness and number of reproductive modes in Brazil. J. Trop. Ecol. 2010 Jul;26(4):423-32. doi: $10.1017 / \mathrm{S} 0266467410000167$.

57 Duellman WE, Trueb L. Biology of Amphibians. New York: McGraw-Hill Book Company; 1994. 